(Gdańsk)

\title{
TAJEMNICA KRZYŻA CHRYSTUSA W LISTACH ŚW. HIERONIMA*
}

„Przy każdym wejściu i wyjściu, przy każdym początku i końcu, podczas wkładania ubrania i butów, przed kąpielą, kiedy siadamy do stołu, kiedy kładziemy się na spoczynek lub siedzimy na krześle, przy każdej codziennej czynności znaczymy czoło znakiem krzyża." - tak pisał Tertulian w swoim dziele $D e$ corona $^{1}$. Bezsprzecznie można powiedzieć, że Hieronim wyrasta, a także jest spadkobiercą i kontynuatorem powyższej tradycji ${ }^{2}$, również w tym, co odnosi się do Tajemnicy Krzyża Chrystusa ${ }^{3}$. Faktem jest, że osobowość, jak i typ charakteru Hieronima ukazują ową tradycję w odcieniu typowym dla jego osobistych spostrzeżeń i poglądów odnośnie do poruszanego tematu.

Skupiając się w głównej mierze na epistolarnej twórczości Hieronima, poddając ją analizie, chciałbym ukazać ich autora, jako osobę głęboko doświadczającą tajemnicy Krzyża oraz dzielącą się tym doświadczeniem ze swoimi korespondencyjnymi odbiorcami ${ }^{4}$, jak i udzielającą im wskazań odnośnie właściwego przeżywania tej tajemnicy w ich osobistym życiu ${ }^{5}$. Hieronim zatem zakotwiczony w owej tradycji będzie ukazywał w swoich listach osobiste doświadczenie krzyża, związane z jego rozumieniem w kategoriach pojęć mu dostępnych. To świadectwo krzyża w życiu Hieronima okazało się być tak

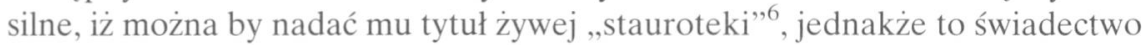
trzeba rozumieć jedynie jako poczucie czegoś, co wykracza poza ludzką wy-

W artykule korzystano z ed. I. Hilberga: Hieronymus, Epistulae, CSEL 54-56, Wien 19101918, tłum. J. Czuj: Św. Hieronim, Listy, I-III, Warszawa 1952-1954.

1 Tertullianus, De corona 3, 4, CCL 2, 1043, cyt. za J. Śrutwa, Najwcześniejsze formy krzyża Chrystusowego, VoxP 3 (1983) z. 4, 176; zob. też. S. Longosz, Znak krzyża świętego w życiu starożytnych chrześcijan, TST 8 (1981) 221-232.

${ }^{2}$ Por. J.N.D. Kelly, Hieronim. Życie, pisma, spory, tłum. R. Wiśniewski, Warszawa 2003, 43, 54 i 78 ,

${ }^{3}$ Por. Hieronymus, Epistula 22, 37, CSEL 54, 202, Czuj I 155: „Przy każdej czynności, przed każdym wyjściem niech ręka kreśli krzyż".

${ }_{4}$ Por. Epistula 1, 2.

5 Por. Epistulae 14, 6 i 22, 37. 
obraźnię i ludzkie doświadczenie, w końcu jako tajemnicę, która wyrywa się ku tajemnicy Boga.

Materiał dostępny w listach jest raczej materiałem przygodnym, gdyż żaden z listów nie jest traktatem o krzyżu w sensie dosłownym. Wychodząc z założenia, że Hieronim był jednym z największych egzegetów, omówienie powyższej tematyki rozpocznę od przedstawienia biblijnych figur krzyża i ich przesłania oraz znaczenia dla zrozumienia dramatu Krzyża, a następnie przechodząc od dramatu Krzyża wiążącego się ściśle z osobą Jezusa Chrystusa uwydatnię swoistego rodzaju entuzjazm, który w swoich konsekwencjach wśród wyznawców Chrystusa, rzecz jasna w rozumieniu Hieronima, był posunięty aż do „,szaleństwa krzyża”?.

1. Biblijne formy krzyża i ich przesłanie. Hieronim wskazuje i odwołuje się do figur krzyża, zawartych w Starym Testamencie, a także do tzw. cruces dissimulatae $e^{8}$ pierwszych chrześcijan, by wskazać na tajemnicę, której treść Bóg zakrył przed Żydami, później zaś przez chrześcijan była strzeżona jako mądrość, która głupstwem była dla pogan, a przekleństwem dla Żydów. Pierwszym tak zwanym „krzyżem ukrytym”, jaki na podstawie wspomnianej tradycji jest możliwy do rozpoznania w listach Hieronima, jest „maszt”:

„Oto teraz znika mi sprzed oczu, a zewsząd niebo i zewsząd morze [...]. Wzywasz mnie, bym żagle wciągnął na maszt [...] kierował sterem"'.

W liście do papieża Damazego, mówiącym o Serafinach i kamyku, zapowiedzią krzyża jest hebrajska litera „Tau”, którą określa, jako światłość oblicza Pańskiego ${ }^{10}$, w której to z kolei światłości zawarta jest prawda, której strzegą Boży aniołowie. Prawdę tę Hieronim odczytuje w takich figurach, jak: brama, kleszcze w łączności z kamieniem oraz klucz ${ }^{11}$. Wypowiedzi Hieronima zawarte w tym liście są streszczeniem całej tradycji mówiącej za pomocą figur i ukrytych znaczeń, gdy rzecz odnosi się do faktu przyjścia Zbawiciela i sposobu przepo-

${ }^{6}$ Por. Epistula 22, 30; zob. Nowa encyklopedia powszechna PWN, VI, Warszawa 1996, 38: „Stauroteka [gr.], relikwiarz w formie krzyża, przeznaczony do przechowywania relikwii drzewa Krzyża Św.; wykonany przeważnie ze szlachetnego metalu i bogato zdobiony”.

${ }^{7}$ Por. H.I. Marrou, Kościót w tonie kultury hellenistycznej i rzymskiej, tłum. L. Bieńkowski, „Concilium” 1971, z. 1-10, 328.

${ }^{8}$ Crux dissimulata - symboliczny obraz znaku krzyża, najczęściej ukryty w figurach przedstawiających obraz łodzi z masztem, kotwicy, drabiny, klucza, siekiery, miecza itp. Więcej na ten temat por. S. Kobielus, Krzyż Chrystusa, Warszawa 2000.

9 Epistula 1, 2, CSEL 54, 2, Czuj I 2.

${ }^{10}$ Por. Epistula 18,1.

11 Por. Epistula 120, 9, CSEL 55, 494, Czuj III 113: ,tego dnia, kiedy (Chrystus) zmartwychwstał [...], wszedł do Apostołów przez zamknięte drzwi [...]”. Przez analogię można odczytywać ten fragment wypowiedzi Hieronima, jako potwierdzający fakt, że Krzyż, który wówczas był tożsamy z osobą Chrystusa, był też rozumiany jako „,klucz”. 
wiadania o Nim, jak i tego, w jaki sposób sam Zbawiciel podniesie ludzkość do chwały niebios $^{12}$. W liście tym słowo Boże, tj. Chrystus jest przedstawiany jako kamień, który unoszony jest za pomocą kleszczy, by oczyszczać, tak aby wszyscy czujący bojaźń przed Bogiem zostali odziani w moc miecza ${ }^{13}$. Kleszcze, jak i miecz są figurami krzyża, a tym samym i tego, z narodzeniem którego ,doszło zbawienie aż do nieba, tj. także na wysokości; wtedy pokój nastał nie tylko na ziemi, ale i w niebie, aby już wreszcie przestano mówić: «Upił się na niebie miecz mój» (Iz 34, 5) ”14. W liście do papieża Damazego, „O dwóch synach”, Hieronim ponownie powraca do litery „Tau”, która będąc światłością oblicza samego Pana jest jednocześnie znakiem, którym oznacza się wybranych ${ }^{15}$. Tych to Bóg wyławia z władania śmierci, jakby za pomocą wędki, na końcu której zawieszony jest hak, bądź kotwica, tj. krzyż, na którym Chrystus jest przynętą dla Lewiatana ${ }^{16}$, wroga człowieka i posiadacza wielu imion ${ }^{17}$, przy pomocy których sprowadza ludzkość ku zagładzie. Ten Chrystus zaś stając się przynętą, uwalnia ludzi, którzy przed jego przyjściem dali się zwieść, by mogli obchodzić z nim szabat w przyszłym królestwie, tzn. uczestniczyć z Nim w tej samej chwale ${ }^{18}$. W tak zwanym traktacie o dziewictwie, jak powszechnie określa się 22 list Hieronima skierowany do Eustochium, jego autor wskazuje na jeszcze jedną figurę krzyża powszechnie znaną ówczesnej tradycji, a mianowicie na drabinę ze snu Patriarchy Jakuba:

„Upadł Lucyfer [...]. Rzekł bowiem [...]: «Wstąpię na wysokość obłoków, będę podobny Najwyższemu» (Iz 14,14). Dlatego też co dzień mówi Bóg do owych schodzących po drabinie, która Jakub widział we śnie: «[...] Bogami jesteście i synami Najwyższego wszyscy. Ale wy pomrzecie jako ludzie [...]» (Ps 81, 6). Upadł bowiem najpierw szatan i podczas gdy Bóg stanął w zgromadzeniu bogów i w pośrodku bogów sądzi, to Apostoł pisze tym, którzy przestają być bogami: «Skoro bowiem między wami zazdrość i niezgoda panuje, czyż nie jesteście cieleśni i czy nie postępujecie według zasad czysto ludzkich?» (1Kor 3, 3)"19.

12 Por. Epistula 18, 7-9.

13 Por. Epistula 18, 18-19; 22, 4.

14 Epistula 20, 5, CSEL 54, 110, Czuj I 83.

15 Por. Epistula 21, 24. 27.

16 Por. Epistula 60, 2, CSEL 54, 550, Czuj II 11: „Przez Jego śmierć ty umarłeś, przez Jego śmierć my żyjemy. Pożarłeś i pożarta zostałaś; i gdy podniecona przynętą przywłaszczonego sobie ciała chciwą gardzielą pochłaniasz łup, wnętrzności twoje zostały rozdarte ostrym zębem"; zob. Kobielus, Krzyż Chrystusa, s. 152.

17 Por. Epistulae 21, 11; 60, 3-4.

18 Por. Epistula 36, 16. Hieronim idąc za obowiązującą wówczas teologią odczytuje znak krzyża w kategoriach chwały, a przesiąknięty teologią św. Pawła Apostoła rozwija koncepcję uznania krzyża za zwięzłe zobrazowanie tego, co poprzez śmierć Chrystusa staje się ideogramem zbawienia.

19 Epistula 22, 4, CSEL 54, 149, Czuj I 114; por. Epistula 3, 4, CSEL 54, 15, Czuj I 12: „Bonozus [...] wstępuje już po owej drabinie, którą Jakub widział we śnie; niesie krzyż swój [...]. Oto młodzieniec [...] nowy osadnik raju [...] będzie uniesiony na obłoki naprzeciw Chrystusa. [...] z boku Pana pić będzie”. 
Zatem, jak wynika z powyższych zestawień, Hieronim ukazuje istnienie pragnienia całego stworzenia odnośnie do objawienia Krzyża, a przez to odzyskania harmonii zachwianej przez nieposłuszeństwo ,żyjących" ${ }^{20}$ Bóg przyjmując cały ból świata, odnawia harmonię przez objawienie krzyża, który jednych wywyższy przez wydobycie z mroków ku światłu, a tych którzy od początku przeznaczeni byli do niesienia światła, a sprzeciwili się temu zadaniu, obezwładni, przezwycięży i odbierze im ostatecznośćc ${ }^{21}$.

Kolejną figurą krzyża przekazaną przez Stary Testament jest według zamysłu Hieronima siekiera ${ }^{22}$ i związana $\mathrm{z}$ nią pośrednio inna figura symbolizująca pogańską myśl, którą wyraża litera „Y”. Litera ta według myślicieli pogańskich była symbolem drogi życia rozgałęziającej się w dwie strony - ku drodze cnoty z jednej strony, a z drugiej ku występkom i zagładzie. Tłumaczenie to zostało doskonale zaakceptowane przez moralistykę żydowską i chrześcijańską, a przez Hieronima w kontekście chrztu zinterpretowane następująco:

„Kto jednak jest dzieckiem i rozumuje jak dziecko, tego zarówno złe, jak i dobre uczynki, dopóki nie dojdzie do wieku rozumnego i litera pitagorejska nie zwiedzie go na rozstajne drogi, idą na rachunek rodziców"23.

Hieronim jako wybitny biblista i znawca kondycji psychiki ludzkiej, dostrzegając owe figury, jak i tzw. cruces dissimulatae uwrażliwia, aby nie skupiano się tylko na samych interpretacjach ${ }^{24}$. Hieronim, gdy mówi o figurach krzyża, jednoznacznie ma na myśli osobę Chrystusa ${ }^{25}$, który na krzyżu objawił i zrealizował wszystkie zapowiedzi Starego Testamentu, sięgające osoby Melchizedeka, tego, który „,chleb i wino ofiarował i objawił tajemnicę chrześcijańską kryjącą się w Ciele i Krwi Zbawiciela"26.

2. Dramat Krzyża. ,Może w myśli zganisz nas, że nie trzymamy się porządku Pisma, lecz tak na chybił trafił [...], omawiamy bez porządku i powierzchownie. Ale [...], miłość nie trzyma się kolejności, a niecierpliwość nie zna miary stąd w Pieśni nad Pieśniami poleca się jako rzecz trudną: «Uporządkujcie we mnie miłość» (Pnp 2, 4); to samo my teraz mówimy błądząc nie niewiedzą, lecz

${ }^{20}$ Por. Epistula 22, 4.

${ }^{21}$ Por. Epistulae 57, 9; 121, 8; 154, 1, CSEL 56, 367, Czuj III 482: „Należy ich zgładzić, duchowo zabić, przebić mieczem Chrystusowym, skoro przez okłady i łagodne leczenie nie mogą odzyskać zdrowia".

${ }^{22}$ Por. Epistulae 106, 85-86; 109, 4, CSEL 55, 356, Czuj III 9: „Mógłbym więcej napisać [...], by mógł usłyszeć Jana Chrzciciela: «Już siekiera do korzenia drzew przyłożona jest. Przeto wszelkie drzewo, które nie daje owocu dobrego, będzie wycięte i w ogień wrzucone» (Mt 3, 10)".

${ }^{23}$ Epistula 107, 6, CSEL 55, 297, Czuj II 407.

24 Por. Epistula 21, 13.

25 Por. Epistula 15, 2.

26 Epistula 46, 2, CSEL 54, 331, Czuj I 258; por. Epistula 73, 4, CSEL 55, 17, Czuj II 141: „Wszystko to, co następuje na pochwałę Melchizedeka, odnosi się do figury Chrystusa [...]”. 
uczuciem. Zresztą [...], powtórzyć należy dawniejsze rzeczy"27 - tak pisał Hieronim do Marceli w imieniu swoich uczennic Pauli i Eustochium, przebywających w Ziemi Świętej ${ }^{28}$. Jego ideą było doprowadzenie swoich odbiorców do punktu zwrotnego w ich życiu, to jest do punktu, gdzie zaczyna się dramat Krzyża $^{29}$. Aby jednak każdy z nich mógł go dobrze odczytać, w kontynuacji powyższych słów korespondencji, Hieronim wprost wskazuje na Chrystusa, jako Tego, w którym wszystkie figury krzyża znajdują swoje dopełnienie i ostateczną interpretację:

„W tym mieście [Jerozolimie], a nawet w tym samym miejscu, gdzie nasz Pan był ukrzyżowany, miał żyć ongiś i umrzeć Adam. Stąd i miejsce to nazywa się Kalwaria, dlatego, że tam miała być pochowana czaszka pierwszego człowieka ${ }^{30}$, aby krew drugiego Adama - Chrystusa, spływająca z krzyża, zmyła grzechy pierwszego człowieka [...] i by wtedy mogły się spełnić słowa Apostoła: «Zbudź się, który śpisz, i powstań z martwych, a oświeci cię Chrystus[...] Pan panujący i Król królów» $(\text { Ef } 5,14)^{\prime 31}$.

Hieronim nie rozdziela osoby Zbawiciela od samego krzyża w sensie dosłownym, ale oddziela jakby Jego samego od tych, co są ,jakby martwi”. Stąd widać, że ów dramat Krzyża jest dramatem całego universum, w tym przede wszystkim człowieka ${ }^{32}$. Dramat ten wbrew pozorom ma wydźwięk pozytywny, gdyż stanowi on część składową procesu doskonalenia człowieka - rodzaju ludzkiego. Bóg bowiem jakby obrazowo, w osobie Jezusa Chrystusa prezentuje podstawową i jedyną Prawdę godną wiary, która wcześniej była przedstawiana za pomocą figur, pojęć i symboli. Potrzebny był dramat Krzyża, by człowiek uzmysłowił sobie, że w osobie Chrystusa otrzymuje siłę, która umożliwia mu panowanie nad grzechem i złem:

„Nigdy bowiem nie błądzi ten, który naśladuje Prawdę. [...] kto twierdzi, że przebywa w Chrystusie, powinien też postępować tak, jak on postępował. [...] Chrystus cierpiał za nas [...], abyście wstępowali w jego ślady. A on grzechu się nie dopuścił ani też zdrada nie postała w ustach jego. Gdy mu złorzeczono, nie złorzeczył [...]. On sam w ciele swoim zaniósł grzechy nasze na krzyż, abyśmy [...], żyli dla sprawiedliwości”33.

Ten akt miłosierdzia, jak można zauważyć angażuje podmiotową osobowość człowieka, a jako podmiot Bożego planu zbawienia otrzymuje swój czas ${ }^{34}$ tak,

${ }^{27}$ Epistula 46, 3, CSEL 54, 331-332, Czuj I 258.

28 Por. Kelly, Hieronim, s. 144.

29 Por. Epistula 118, 4.

${ }^{30}$ Hieronim w późniejszym czasie odrzuci tę tradycję w Komentarzu do Mateusza 27, 33.

31 Epistula 46, 3, CSEL 54, 332, Czuj I 258.

${ }^{32}$ Por. Epistula 20, 5; 22, 39-40.

33 Epistula 148, 12, CSEL 56, 339, Czuj III 454.

${ }^{34}$ Por. Epistula 121, 7. 
aby gdy „,nadejdzie koniec wszystkich rzeczy”, był „wszystkim we wszystkich, by poszczególni święci mieli wszystkie cnoty i by był Chrystus cały we wszystkich" ${ }^{35}$. Hieronim w związku z tym zauważa, że chociaż w ukrzyżowaniu zawarta jest treść przekleństwa, to jednak jest to interpretacją i głupotą pogan oraz Żydów, którzy kierując się nie duchem, lecz literą prawa uważali, że: „Przeklęty bowiem wszelki, który zawisł na drzewie” (por. Gal 3, 13; Pwt 21, $23)^{36}$. Hieronim jednak dodaje do tego własną interpretację, która aspekt przekleństwa ukazuje w wymiarze pozytywnym w odniesieniu do wierzących w Chrystusa, bowiem w Chrystusie - Ukrzyżowanym objawiła się miłość, która uwolniła ludzi z mocy śmierci, oddając ich na powrót Życiu:

„Dziwisz się więc, że ten, który za nas stał się przekleństwem, by nas od przekleństwa uwolnić - jest dla nas poddany, by nas Ojcu uczynić poddanymi, jak mówi $[\ldots]$ [.«Gdy nad ziemię podwyższony będę, wszystko do siebie przyciągnę» (J 12, $32)^{37}$. Chrystus w tych, którzy mają wiarę, poddany jest Ojcu, ponieważ wszyscy wierzący, a nawet cały rodzaj ludzki uważany jest za jego członki: «[...] by ludzkość była poddana Boskości»" ${ }^{\text {38. }}$.

Dziwne jest jednak to, że Hieronim w jakiś sposób chciałby wykluczyć z owej „Boskości” pogan, żydów i heretyków, interpretując dramat Krzyża jako zgubny dla tej części ludzkości:

„W tych zaś, którzy nie mają wiary, tj. w żydach, poganach, heretykach, nie jest poddany - jak się mówi - ponieważ część jego członków nie jest poddana wierze" ${ }^{\text {39. }}$.

Wypowiedź Hieronima jest nad wyraz lakoniczna, jednakże nie wyklucza tej części ludzkości z możliwości poddania tejże „Boskości”, gdyż to, według jego słów „ludzkość” ma być poddana, a nie jej część. To cała ludzkość przynależy do Ciała Chrystusa, jako Jego członki, bo też całe ciało zostało poddane ukrzyżowaniu, a więc wszyscy zostali włączeni w pełnię tajemnicy krzyża. A tym samym, każdy mający udział w owej Pełni, będzie musiał stanąć przed trybunałem Chrystusowym, by zdać sprawę z tego, czy trzymał się drogi Krzyża, czy może dał się zwieść „literze pitagorejskiej”40.

3. Znak zwycięstwa. Krzyż znak zwycięstwa spełnia u Hieronima funkcję apotropaiczną $^{41}$, sięgającą aż do głębi serca ${ }^{42}$, z którego ma wypływać pragnie-

\footnotetext{
35 Epistula 55, 3, CSEL 54, 491, Czuj I 387.

36 Tamże, CSEL 54, 490, Czuj I 386.

37 Tamże, CSEL 54, 490-491, Czuj I 386-387.

38 Tamże, CSEL 54, 491, Czuj I 387.

39 Tamże.

40 Por. Epistulae 107, 6; 148, 9-10.

${ }^{41}$ Por. Epistula 22, 37.

42 Por. Epistulae 66, 10; 149, 4.
} 
nie jeszcze gorliwszego naśladowania Chrystusa ${ }^{43}$, aż do oddania za Niego życia. W osobie wyrażającej taką bowiem postawę, obecne jest tchnienie ogień $^{44}$, który przenika tajniki ludzkiej duszy, i tak tą osobę przemienia, że ze „starego" człowieka czyni „nowym” oraz gotowym, aby dać świadectwo swojej wierności Chrystusowi ${ }^{45}$. Oddanie życia na świadectwo wierności Chrystusowi, według Hieronima nie musi się wyrażać w sposób ścisły poprzez przelanie krwi, bowiem, jak pisze, ,zespolenie więzami Chrystusowymi” wyraża się również poprzez bojaźń Pańską i studia nad Pismami Bożymi ${ }^{46}$, a nad to i przez wewnętrzny lub zewnętrzny sprzeciw odnośnie postępowania pogan ${ }^{47}$, żydów ${ }^{48}$ oraz heretyków ${ }^{49}$, którzy swoimi naukami sprowadzają najpierw na siebie potępienie, a następnie na tych, którzy im oddają posłuch ${ }^{50}$.

W liście do Innocentego podekscytowany wydarzeniem, które opisuje, Strydończyk uświadamia czytelnikowi, że męczeństwo nie musi kończyć się śmiercią, i że wierność Chrystusowi - Krzyżowi, prowadzi do życia, a brak bojaźni ku śmierci. Hieronim stosuje w opisie tzw. „ukryty krzyż”, wyrażający się w obrazie „miecza" ${ }^{\text {. }}$. W tym dopiero bowiem kluczu jasnym się staje opis tortur, gdzie to Krzyż - Chrystus jest sędzią i wykonawcą wyroku. Wymownym obrazem tego, że miecz jest uznawaną przez Hieronima figurą zapowiadającą krzyż Chrystusa, jest wyjaśnienie znaczenia postępowania Salomona, w liście skierowanym do kapłana Rufina, jako zapowiedzi postępowania Zbawiciela ${ }^{52}$. Nasz Ojciec Kościoła poprzez te wypowiedzi wskazuje również na bardzo znaczący w tej kwestii element, a mianowicie na różnicę, jaka zachodzi pomiędzy Bożym Miłosierdziem, a ludzkim współczuciem i litością ${ }^{53}$. Ukazuje również zasadniczą prawdę, związaną z Tajemnicą Krzyża, która w swojej istocie odnosi się do właściwego rozumienia miłosierdzia. Dla pogan będzie to głównie akt litości i ludzkiego współczucia, podyktowanego nie zrównoważeniem emocjonalnym, zaś dla wierzących w Chrystusa, który poniósł grzechy ludzkości wszystkich wieków

43 Por. Epistulae 148, 12.

44 Por. Epistula 120, 11, CSEL 54, 510, Czuj III 146: „Triumfem Boga jest cierpienie męczenników, przelanie krwi w imię Chrystusa i radość wśród tortur. [...] Jesteśmy na każdym miejscu miłą Bogu wonią imienia Chrystusowego i tchnie wzdłuż i wszerz żarliwość naszego przepowiadania”; Epistula 121, 2, CSEL 56, 5, Czuj III 162: „Chrystus [...] z małej iskry [...] wzniecił olbrzymie pożary, tak iż cały świat rozgorzał ogniem Zbawiciela Pana. [...] aby się palił we wszystkich."

${ }^{45}$ Por. Epistulae 18, 18; 120, 12.

46 Por. Epistula 53, 1.

47 Por. Epistula 58, 3-4.

48 Por. Epistula 21, 34.

49 Por. Epistulae 107, 6; 123, 11, CSEL 56, 84, Czuj III 225: „tak heretycy rozrywają jeden Kościół na wiele poszczególnych Kościołów, które według objawienia Jana winny się nazywać raczej synagogami szatana, niż zgromadzeniami Chrystusa".

50 Por. Epistula 121, 11.

51 Por. Epistula 68, 1.

52 Por. Epistula 74, 5.

53 Por. Epistula 1. 
w swoim ciele na drzewo krzyża ${ }^{54}$, będzie on łaską Życia, tzn. łaską daną darmo od samego Chrystusa ${ }^{55}$. Hieronim wyraźnie uwypukla prawdę, odnoszącą się do sług Chrystusa, że pomimo zakusów i ataków szatana i jego sług, sam Zbawiciel będzie stawał w ich obronie ${ }^{56}$, gdyż należą do Niego ${ }^{57}$ przez poddaństwo wierze, natomiast ci, co się sprzeciwiają, należą do Antychrysta ${ }^{58}$, który parodiuje Chrystusa $^{59}$. Święty Doktor poruszając zagadnienie miłosierdzia, dotyka także różnego rodzaju jego odniesień, i tak w stosunku do upadających w wierze pisze, że Chrystus nawiedzi ich przestępstwa rózgą, a grzechy biczami ${ }^{60}$. W przypadku zaś pogan i wiarołomnych, będzie to wieczne zawstydzenie, bo:

„Nic tak Boga nie obraża, jak trwanie w złem przez zwątpienie w dobro, chociaż sama rozpacz jest oznaką braku wiary. Ten bowiem, kto traci wiarę w zbawienie, nie wierzy w nadejście sądu. Gdyby się go lękał, przygotowałby się do niego z pewnością przez dobre uczynki” ${ }^{\circ 1}$.

Powyższą sprawę Hieronim przedstawił bardziej szczegółowo w liście skierowanym do mnichów Minerwiusza i Aleksandra:

„Kto bowiem całym sercem ufa Chrystusowi, chociażby jako człowiek ułomny umarł w grzechu, przez wiarę swoją żyje na wieki. Zresztą owa wspólna śmierć odnosi się i do wierzących i do niewierzących, i wszyscy razem zmartwychwstaną, jedni na zawstydzenie wiekuiste, drudzy, ponieważ wierzą, na żywot wieczny"62.

Tak więc owi poganie i wiarołomni ,zmartwychwstaną [...] na zawstydzenie wiekuiste", gdyż nie poddali się Chrystusowi, a kierując się szatańską intrygą prześladowali Jego wiernych świadków, nazywając ich pełnymi hańby, kameleonami, ludźmi zdradliwymi, kłamcami i zwodzicielami ${ }^{63}$. Hieronim upatruje wiarę prześladowanych w ich osobistym stosunku do krzyża Pańskiego, który jest dla nich chorągwią pobożności ${ }^{64}$, a przez to także znakiem, dzięki któremu odnoszą pełne zwycięstwo nad każdym przejawem zła $^{65}$, uprzednio oczywiście

${ }^{54}$ Por. Epistula 148, 12, CSEL 56, 339, Czuj III 454: „On sam w ciele swoim zaniósł grzechy nasze na krzyż, abyśmy umarłszy dla grzechów, żyli dla sprawiedliwości”.

55 Por. Epistula 1, 5-6. 9-11.

56 Por. Epistula 3, 5.

57 Por. Epistula 109, 1.

58 Por. Epistula 15, 2.

59 Por. Epistula 22, 38.

${ }^{60}$ Por. Epistulae 21, 34; 36, 2-3.

${ }^{61}$ Epistula 122, 1, CSEL 56, 58, Czuj III 203.

62 Epistula 119, 7, CSEL 55, 457, Czuj III 101.

63 Por. Epistulae 45, 2; 64, 21, CSEL 54, 614, Czuj II 55: „O, ileż dziewic i iluż ludzi, których uważana za czystych, będzie zawstydzonych w dzień sądu, a iluż ludzi, których czystość została zniesławiona, Boski Sędzia ukoronuje".

${ }^{64}$ Por. Epistula 45, 4.

65 Por. Epistulae 39, 2-3; 65, 10. 
jednocząc się jak najpełniej z Chrystusem w Jego męce i śmierci, gdyż, jak sam zauważa, do raju wchodzi się przez krzyż ${ }^{66}$. Strydończyk w tej kwestii ma głównie na myśli osoby, które zajęły miejsca męczenników, a były określane jako te, które poddały się „bezkrwawemu męczeństwu”, poprzez zachowywanie dziewictwa i prowadzenie życia ascetycznego, wyrażającego się w zachowywaniu cnoty czystości i umartwieniu ciała, oddaniu modlitwom, postom i uczynkom miłosiernym ${ }^{67}$.

Hieronim, mnich, intelektualista, w odróżnieniu od ówczesnych mu sławnych postaci dostrzegł, że Bóg przez dramat krzyża uzdolnił człowieka do przyjmowania daru, którym jest życie w pełnej jedności z Chrystusem. Pisząc w głównej mierze do kobiet, swoje doświadczenie krzyża ukazuje jako doświadczenie miłosnego zjednoczenia ich dusz z Duchem Chrystusa, który nadchodzi $^{68}$. Nasuwa się tym samym wniosek, że Chrystus przez krzyż, według niego, staje się jakby bezradny, by przez tchnienie swego Ducha w swoich wiernych poddać ich swemu działaniu i włączyć w swoje dzieło zbawcze ${ }^{69}$, czyniąc $\mathrm{z}$ nich przez ich wiarę w Niego synami Bożymi ${ }^{70}$.

4. W blasku Chwały Ukrzyżowanego. W liście skierowanym do mnicha Heliodora, Hieronim pisał:

„Od dni bowiem Jana Chrzciciela królestwo niebieskie gwałt cierpi i gwałtownicy porywają je. Płomienny ów miecz na straży raju i czuwające u wejścia cherubiny zostały zgaszone krwią Chrystusa, a brama na nowo otwarta. I nic dziwnego, że to nam jest w zmartwychwstaniu przyobiecane, ponieważ wszyscy, którzy żyjemy $\mathrm{w}$ ciele, lecz nie według ciała, w niebie mamy mieszkanie [...]" ${ }^{\prime 1}$.

Powyższa zacytowana wypowiedź Hieronima pokazuje, że wszystko co w jakiś sposób odnosiło się do zapowiedzi krzyża w Starym Testamencie, z nastaniem dramatu krzyża straciło swoją tajemniczość i w pełni odkryło prawdziwy blask chwały nie krzyża, który ,jest chwałą Zbawiciela triumfującego"72, lecz samego Ukrzyżowanego:

„I nie sądź od razu, że Pismo zawiera sprzeczności, dlatego że w jednym miejscu jest mowa o poniżeniu ciała z powodu chłosty, oplwania, policzków, gwoździ i hańby krzyża, w drugim zaś o piękności cnót w świętym i czcigodnym ciele. Nie o to chodzi, że Chrystus jako Bóg jest piękniejszy w porównaniu z ludźmi,

\footnotetext{
${ }^{66}$ Por. Epistula 125, 1.

${ }^{67}$ Por. Epistulae 22, 21, 23; 108, 15.

${ }^{68}$ Por. Epistula 39, 3.

${ }^{69}$ Por. Epistula 121, 3.

${ }^{70}$ Por. Epistula 121, 8.

71 Epistula 60, 3, CSEL 54, 552, Czuj II 12.

72 Epistula 120, 9, CSEL 55, 493, Czuj III 132.
} 
bo tu nie ma żadnego porównania, ale to, że jest piękniejszy ponad wszystko, z wyjątkiem męki krzyża",73.

Hieronim w sposób wyraźny ukazuje prawdę o tym, że przez znak przynależności do Ukrzyżowanego ${ }^{74}$ wierzący w Niego będą mieli udział w tej samej chwale: ,ilu nas bowiem w Chrystusie jest ochrzczonych, przyoblekamy się w Chrystusa"75. Człowiek zanurzony w chrzcie razem z Chrystusem, razem z Nim umiera i razem z Nim zmartwychwstaje odnosząc triumf w Jego zwycięstwie:

„Chrystus jest uświęceniem, bez którego nikt nie będzie oglądał oblicza Boga; Chrystus odkupieniem, On sam Odkupicielem i zapłatą; Chrystus wszystkim, tak że kto by wszystko dla Chrystusa opuścił, za wszystko znajdzie Jego jedynego i będzie mógł swobodnie wołać: «Pan częścią moją» (Ps 72, 26)»"76.

Osoba odrodzona w Chrystusie, nosząca ,znamię świata”, to jest chlubę krzyża „Pana naszego Jezusa Chrystusa" ${ }^{, 77}$ stanowi z Nim jedno ${ }^{78}$ i ma udział w blasku Chwały Ukrzyżowanego ${ }^{79}$. Chlubą jest wiekuista radość i wieczne świętowanie w życiu Boga, tzn. przez Chrystusa Ukrzyżowanego w życiu Trójcy Świętej ${ }^{80}$. Natomiast to, co odnosi się do życia w blasku Chwały Ukrzyżowanego oznacza życie w Jego mocy ${ }^{81}$, tak by Jego oblicze ukazało się poprzez nasze serca w jasnym świetle Jego i naszego Ojca ${ }^{82}$, „który sprawia, że słońce jego wschodzi nad dobrymi i złymi, a deszczem zrasza sprawiedliwych i niesprawiedliwych" (por. Mt 5, 45) ${ }^{83}$. Pełniący dzieła miłosierdzia stają się naczyniami

${ }^{73}$ Epistula 65, 8, CSEL 54, 625, Czuj II 63; por. Epistula 120, 5, CSEL 55, 486, Czuj III 126: „[...] ciało ludzkie zostało przemienione w chwałę bóstwa [...]”.

${ }^{74}$ Por. Epistula 60, 10.

75 Epistula 64, 5, CSEL 54, 593, Czuj II 41; por 64, 7, CSEL 54, 594, Czuj II 42: „chwała Pana jest chwałą sług - i gdziekolwiek nadarzy się sposobność, będę rozprawiał o światłości prawdziwej tak, żeby opromieniała także i tych, którym Chrystus to sprawił, aby byli światłością".

76 Epistula 66, 8, CSEL 54, 658, Czuj II 89; por. Epistulae 65, 11, 14; 69, 7.

77 Por. Epistula 100, 4-5.

78 Por. Epistulae 75, 2; 120, 12: „dwoje jednym uczynił”; 65, 5, CSEL 54, 622, Czuj II 61: „Dobry człowiek spożywając napełnia duszę swą, a gdy się nasyci świętymi naukami, wydobywa z dobrego skarbca serca to, co jest dobre, i mówi z Apostołem: «Czyż chcecie doświadczyć Chrystusa mówiącego przeze mnie» (2Kor 13, 3)".

79 Por. Epistula 14, 2-3, CSEL 54, 46-47, Czuj I 35: „Przypomnij sobie dzień twego zaciągu, w którym, z Chrystusem we chrzcie współpogrzebany, złożyłeś przysięgę na słowa sakramentu, że dla jego imienia nie będziesz oszczędzał ani matki, ani ojca [...]. Oto wróg pragnie daru, który otrzymałeś jako zadatek na przyszłą służbę. [...] otarłszy łzy biegnij pod znak krzyża. [...] przyjdzie potem dzień, w którym jako dzielny zwycięzca powrócisz do ojczyzny; w dzień ów kroczyć będziesz w koronie jako dzielny mąż po niebieskiej Jerozolimie."

${ }^{80}$ Por. Epistulae 100, 11, 16-17; 120, 11.

81 Por. Epistula 119, 9.

82 Por. Epistula 119, 11.

83 Epistula 120, 1, CSEL 55, 476, Czuj III 117. 
chwały ${ }^{84}$, bowiem ,życie nasze ukryte jest z Chrystusem w Bogu. Gdy Chrystus, życie nasze, ukaże się, tedy i my ukażemy się razem z nim w chwale" (por. Kol 3, 3-4 $)^{85}$. Do czasu jednak, gdy przychodzi żyć człowiekowi w śmiertelnym ciele, poddany jest niejako rozproszeniom, dlatego też krzyż został dany dla umocnienia wszystkich, którzy wierzą w Chrystusa ${ }^{86}$, „,który jest prawdziwym

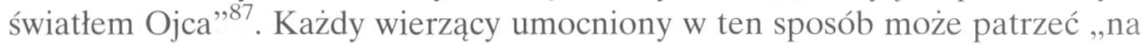
chwałę Pańską” i przemieniać się „w tenże obraz, z jasności w jasność jakby od Ducha Pańskiego [...]. Aż wszyscy zejdziemy się, stawszy się mężami doskonałymi na miarę pełnego wzrostu dojrzałości Chrystusowej” (Ef 4, 13) ${ }^{88}$, tak aby, gdy „ukaże się na niebiosach znak Syna Człowieczego” mógł On sam - zgodnie z wymową znaku - zgromadzić wokół siebie wszystkich wybranych ,z czterech stron świata, od szczytów niebios aż do ich krańców" (Mt 24, 30-31) ${ }^{89}$.

5. Uświęcony przez Krzyż. Hieronim w swoich listach ukazuje się jako osoba doświadczająca religijno - mistycznych uniesień w odniesieniu do Krzyża, jednakże same jego wypowiedzi nie zawsze są koherentne. Jednym z powodów tego może być zapewne fakt, że nie pozostawił on jakiejś konkretnie usystematyzowanej teologii krzyża, jak i to, że sam był świadomy niewyrażalności religijno - mistycznego doświadczenia za pomocą ubogich pojęć swego czasu. Każda bowiem próba opisu za pomocą dostępnego zakresu aparatów pojęciowych ówczesnej teologii doprowadzała go do punktu, gdzie zachodziło tragiczne rozdarcie pomiędzy osądem umysłu a decyzją woli, to znaczy, że skazany był w tych opisach na bardzo nieudolne i lapidarne stwierdzenia. Chcąc zrozumieć to, czego doświadczał Hieronim odnośnie krzyża, trzeba ująć je w kluczu ówczesnej teologii krzyża, gdzie krzyż przede wszystkim nie był rozumiany jako znak haniebnej śmierci, co raczej w ujęciu militarno - heroicznym, jako symbol zbawienia człowieka ${ }^{90}$. Chodzi tu o pewien rodzaj walki przy pomocy krzyża, który jest doskonałym narzędziem pomagającym zwalczać złe żądze, pokusy, nałogi oraz innych sprzymierzeńców przeciwnika postępu duchowego osoby poświęconej Bogu - Szatana. Walka bowiem przy użyciu tej duchowej broni była w pojęciu ludzi epoki, w której żył Hieronim, czymś niezwykle pomocnym w stałej walce przeciwko wszelkim pokusom. W takim też znaczeniu należałoby spojrzeć na doświadczenia, którym był poddany Hieronim, a o których pisze w liście do Eustochium w 384 roku. To co zamyka on w słowie „sen” jest obrazem jego

\footnotetext{
${ }^{84}$ Por. Epistula 120, 10.

85 Epistula 120, 11, CSEL 55, 510, Czuj III 147.

86 Por. Epistula 121, 4-5.

87 Epistula 121, 6.

${ }^{88}$ Epistula 140, 2, CSEL 56, 270, Czuj III 394.

89 Epistula 121, 11, CSEL 56, 52, Czuj III 198.

90 Por. A. Kostołowski, Symbol symboli, „Więź” 27 (1984) z. 8, 55-56.
} 
wewnętrznej walki i dochodzenia do punktu krytycznego, to jest do przyjęcia dramatu Krzyża i zwrócenia całego siebie ku misterium salutis. Strydończyk żyjąc na pustyni przeżył na gruncie religijno-mistycznym swoje oczyszczenie, przeżył swoją noc zmysłów. Ten sen, który jest wewnętrznym obrazem zmagań Hieronima, ukazuje jakby obraz jego przejścia z zależności i udziału w misterium iniquitatis w misterium crucis, tzn. tajemnicę życia w Chrystusie, który w stosunku do niego jest jednocześnie, jak pisze do mnichów Minerwiusza i Aleksandra, transcendentny i immanentny:

„my którzy żyjemy, których ciało martwe jest wskutek grzechu, a duch żyje wskutek usprawiedliwienia [...]. Jak więc ci, którzy pozbyli się obecnego życia i zostali przeniesieni do lepszego, żyją pełniej po wyrzeczeniu się ciała śmierci i wszelkich podniet do grzechów, tak i wszyscy ci, których umartwienie Jezusa w ciele swoim noszą i nie żyją według ciała, lecz według ducha, żyją w tym, który jest życiem, i żyje w nich Chrystus [...]"91.

Idąc bowiem śladami Chrystusa ${ }^{92}$ - jest to duchowa droga Hieronima - przedstawia się on jako osoba, u której miłość ciała jest przezwyciężana miłością ducha, którą jest Chrystus żyjący w nim. Wnikając w dalszą treść listu dostrzega się fakt, że aby przejść ku Tajemnicy Chwały, jakiej doświadcza Chrystus, trzeba pozwolić mu zacząć działać w „wewnętrznym człowieku”. Tego działania Hieronim doświadcza podczas innego snu, który, jak sam określa, nie był snem, czy sennym mamidłem, które często zwodzą ludzi ${ }^{93}$. Sen ten jest tak brzemienny w skutkach dla Hieronima, że pozwala mu odczuć pewność, iż własną siłą niczego nie może osiągnąc ${ }^{94}$ : przeżywając oczyszczenie, nie był wstanie widzieć Chwały, a jedynie swoje ułomności i swoją grzeszność - udział w misterium iniquitatis. Ingerencja Chrystusa po uprzednim przygotowaniu „zewnętrznego człowieka” sprawiła, że zdolny był przyjąć najpierw dramat krzyża, a następnie widząc blask Chwały odzyskać nadzieję na uczestnictwo w owej Tajemnicy, która jest udziałem wszystkich świętych ${ }^{95}$. Hieronim zostaje

91 Epistula 119, 9, CSEL 55, 460, Czuj III 104; por. też Epistula 22, 7. Mowa jest tu o pewnego rodzaju wizji, jaką miał Hieronim podczas przebywania na pustyni. Dręczony wspomnieniami grzesznego życia w Rzymie, zadawał sobie różnego rodzaju umartwienia. Gdzie w pewnym momencie, jak sam relacjonuje, że gdy - czego sam Pan jest mu świadkiem - wylewał łzy patrząc w niebo, zdawało mu się, że jest wśród chórów anielskich, i z weselem oraz radością śpiewał: „Za tobą pobiegniemy do wonności olejków twoich" (Pnp 1,3).

92 Por. Epistula 22, 17

93 Por. Epistula 22, 30, CSEL 54, 189, Czuj I 146. Widzenie to Hieronim miał, jak opisuje, „prawie w połowie Wielkiego Postu”, gdy podążał na „służbę [Bożą] do Jerozolimy”. Historię tę opisuje, w liście skierowanym do Eustochium. Wspomina, że wydarzyła się ona „przed bardzo wielu laty”, gdy wyrzekł się „,dla królestwa niebieskiego domu, rodziców, siostry, krewnych i - co trudniejsze - przyzwyczajenia do wybredniejszego pokarmu".

94 Por. Epistula 59, 3.

95 Por. Epistula 119, 10. 
wydźwignięty w owym śnie, jakby $\mathrm{z}$ otchłani na ziemię ${ }^{96}$, a przez to jakby zostaje wypchnięte z niego zło, które dotąd zadawało mu ból duchowy, a który odczuwa fizycznie po oczyszczeniu przez Chrystusa ${ }^{97}$. Można powiedzieć, że od tego momentu Hieronim staje się prawdziwym wyznawcą Chrystusa, staje się znakiem - osobą ${ }^{98}$, reprezentantem Chrystusa, przyobleczonym mocą z wysokości ${ }^{99}$. Wnioskować można, że blask chwały, jaki przyświecał Hieronimowi, był niczym innym, jak prawdą o zbawczym triumfie Ukrzyżowanego ${ }^{100}$ i tym, że każdy z prawdziwie wierzących w tę prawdę, jest Jego odzwierciedleniem na ziemi wobec pogan, żydów i heretyków, w każdym czasie, na każdym miejscu oraz pod każdym względem. To przyjęcie i zaakceptowanie tej prawdy pozwoliło Strydończykowi uniknąć wiecznej śmierci, tzn. zatracenia w Szeolu. Doświadczenie to odbyło się jakby poza domeną jego zmysłowego i intelektualnego poznania, jednakże liczy się to, że skutkiem tego doświadczenia nastąpiła wewnętrzna przemiana - nawrócenie, moralno - religijna transformacja.

Skandal krzyża stał się początkiem wiary człowieka w Bożą Miłość, która oczyszcza i zwycięża wszelkie zło tkwiące w nim. Objawiony przez Jezusa Chrystusa Bóg Ojciec, podnosi człowieka z jego upadków, a jeszcze bardziej z jego wewnętrznych śmierci. Ten Bóg przez Ukrzyżowanego najbardziej troszczy się o życie człowieka, bowiem chwałą Boga jest żywy człowiek - cały człowiek. Krzyż odnowił życie, które było pasją człowieka, a teraz jest życiem w Duchu Świętym, tj. w chwale Boga Wcielonego, który jako Głowa swego Mistycznego Ciała, doskonali wszystkich przynależących do tego ciała na swoje własne podobieństwo.

Hieronim patrząc z intelektualną miłością na tajemnicę Krzyża widział w niej tajemnicę człowieka oświeconego i podniesionego, tzn. zbawionego w Chrystusie - Ukrzyżowanym, który odradza się w swej tożsamości. Krzyż niezależnie od wszystkich powyższych rozważań, w ujęciu Hieronima był narzędziem, na którym poniósł śmierć Jezus Chrystus, prawdziwy Bóg i prawdziwy Człowiek. Śmierć nie symboliczną, lecz prawdziwą, posiadającą jednoznaczny wymiar odkupieńczy. I tak, jak dwa tysiące lat temu, tak i przez wszystkie dalsze wieki, Krzyż oprócz funkcji jednoczącej dla wielu był, jest i będzie znakiem sprzeciwu.

96 Por. Epistula 60, 14. Fragment tego listu jest obrazem tego, jaki będzie los wierzących w Chrystusa, a mianowicie, że ciała co prawda pójdą do ziemi, ale dusze ich wrócą do Chrystusa.

97 Por. Epistula 22, 30, CSEL 54, 191, Czuj I 147: „Wyznaję otwarcie, że miałem zsiniałe łopatki, że zbudziwszy się ze snu odczuwałem jeszcze razy [...]”.

98 Por. Epistula 107, 1.

99 Por. Epistula 120, 9.

100 Por. Epistula 60, 3. 


\section{SECRET OF THE CROSS OF CHRIST IN THE LETTERS OF ST. HIERONIM}

(Summary)

The author of the article presents issues dealing with the problem named in the topic of the article, confronting them simultaneously with the notions available to the author of letter. One can enumerate the following issues: biblical forms of crosses and their message as well as records and certificates referring to the events, which have given start to the sacralization of the cross. Author indicates also the fact that the declarations of prophets of the Old Testament about Christ have come true, and by Christ both the cross and the people who take the difficulty of seeing the cross as the symbol of salvation of a human rather than an infamous sign of death have been sanctified. 